\title{
THE RISE OF THE ENGLISH DRUGS INDUSTRY: THE ROLE OF THOMAS CORBYN
}

\author{
by
}

\section{ROY PORTER and DOROTHY PORTER *}

Revisionist scholarship over the last generation has immensely sharpened our understanding of medical politics. We no longer see the history of medicine as the straightforward increase of knowledge, science, and skill; or as the rise of colleges, universities, and hospitals, all representing the evolution of a natural division of medical labour; or as the march, onwards and upwards, of professionalism. ${ }^{1}$ Rather, thanks to the writings of Holloway, Waddington, and others, we now construe such issues as reform and professionalization as ideological footballs, kicked around by rival interest groups in endless and unresolved struggles to secure power, prestige, and livelihoods. ${ }^{2}$

But if medical politics has now, rightly, been spotlighted, the economics of medicine remains in the shadows. True, there have been some advances. The researches above all of Raach, Webster, and Pelling for the sixteenth and seventeenth centuries, ${ }^{3}$ of Burnby, Holmes, Lane, and Loudon for the eighteenth, ${ }^{4}$ and of Peterson ${ }^{5}$ for the Victorian age

*Roy Porter, Ph.D., Dorothy Porter, Ph.D., Wellcome Institute for the History of Medicine, 183 Euston Road, London NW1 2BP, U.K.

The authors would like to thank Richard Palmer of the Wellcome Institute for his great help in using the Wellcome Corbyn Papers; they are also most grateful to an anonymous referee for information and correction at many points in this paper.

${ }^{1}$ See P. Wright, 'The radical sociology of medicine', Soc. Stud. Sci., 1980, 10: 103-20; idem and A. Treacher (eds.), The problem of medical knowledge, Edinburgh University Press, 1982, introduction.

2 See, for example, S. W. F. Holloway, 'The Apothecaries' Act 1815. Part 1: the origins of the Act', Med. Hist., 1966, 10: 107-29; 'Part 2: the consequences of the Act', Ibid., pp. 221-36; idem, 'The orthodox fringe: the origins of the Pharmaceutical Society of Great Britain', in W. F. Bynum and Roy Porter (eds.), Medical fringe and medical orthodoxy, 1750-1850, London, Croom Helm, 1986, pp. 129-57; Ivan Waddington, The medical profession in the Industrial Revolution, Dublin, Gill and Macmillan, 1984.

3 J. Raach, A directory of English country physicians 1603-1643, London, Dawson's, 1962; M. Pelling and C. Webster, 'Medical practitioners', in C. Webster (ed.), Health, medicine and mortality in the sixteenth century, Cambridge University Press, 1979, pp. 165-235; M. Pelling, 'Appearance and reality: barbersurgeons, the body and disease', in L. Beier and R. Finlay (eds.), London, 1500-1700: the making of the metropolis, London, Longman, 1986, pp. 82-112; idem, 'Healing the sick poor: social policy and disability in Norwich 1550-1640', Med. Hist., 1985, 29: 115-37.

4 J. G. L. Burnby, A study of the English apothecary from 1660 to 1760 , Medical History Supplement 3 , London, Wellcome Institute, 1983; G. Holmes, Augustan England: professions, state and society 1680-1730, London, George Allen \& Unwin, 1982; Joan Lane, 'The medical practitioners of provincial England in 1783', Med. Hist., 1984, 28: 353-71; idem, 'The provincial practitioner and his services to the poor', Soc. soc. Hist. Med. Bull., 1981, 28: 10-14; Irvine Loudon, 'The nature of provincial medical practice in eighteenth-century England', Med. Hist., 1985, 29: 1-32.

${ }_{5}$ M. J. Peterson, The medical profession in mid-Victorian London, Berkeley and Los Angeles, University of California Press, 1978. 


\section{Roy Porter and Dorothy Porter}

have compelled us to abandon the old idea that common practitioners-as distinct from metropolitan élite physicians-long remained few and impoverished. On the contrary, in numbers, geographical distribution, skill, income, and status, general practitioners formed a major presence at least from late Tudor times onwards, and paradoxically it may have been precisely the nineteenth century which, in an overstocked market, actually saw the erosion, rather than the enhancement, of the prestige and pockets of practitioners at large.

Even so, and despite a few pioneering studies of doctors' ledgers and bank balances, ${ }^{6}$ our understanding of both the incomes of medical practitioners, and, still more important, of how practitioners actually built up their bank balances, guinea by guinea, remains rudimentary. Superiority to filthy lucre formed part of the ethos of the medical hierarchy, and that snobbery seems to have rubbed off on to medical historians, who have almost universally ignored the money side of medicine.

Above all, we know pitifully little about medicine's wider economic structure and networks. Many of its practices were traditionally, of course, highly individualistic, involving direct monetary exchanges between patient and practitioner. Until quite recently, to practise physic or surgery required little capital investment in plant and equipment, nor any organized workforce. It was know-how, skill, and services, rather than commodities, which counted. The practitioner was not "corporate man"; he dealt face-to-face with his client, and not through intermediaries. In these respects, the commercial nexuses which medicine generated remained fairly simple.

But it would obviously be wrong to assume that this face-to-face model offers any complete understanding of the business of medicine. For one thing, individualism was traditionally tempered by collectivism. Guilds, companies, corporations, and colleges set the broad conditions of practice-e.g., entry into the profession-even if they impinged little upon the day-to-day livelihoods of their members. ${ }^{7}$ Thus, in the eighteenth century, one of the informal functions of the new provincial medical societies was to fix fees, and such works as Thomas Percival's Medical ethics (1803) warned practitioners about the evils of price-cutting and fee wars.

Moreover, complex reciprocal ties of clientage, patronage, and mutual interdependency clearly counted for much. Practitioners from different strata had many opportunities to put business in each others' way. For example, as was alleged in a pamphlet, The apothecaries' mirror, or the present state of pharmacy exploded (1790), ${ }^{8}$ physicians would commonly prescribe gallons of medicines to benefit the apothecary, who in turn would reciprocate by recommending only those physicians reputed to

\footnotetext{
6 Irvine Loudon, 'A doctor's cash-book: the economy of general practice in the 1830s', Med. Hist., 1983, 27: 249-68; E. M. Sigsworth and P. Swan, 'An eighteenth-century surgeon and apothecary: William Elmhirst (1721-73)', ibid., 1982, 26: 191-8; D'Arcy Power, 'The fees of our ancestors', in Selected writings 1877-1930, Oxford University Press, 1931, pp. 95-102.

${ }^{7}$ See Sir G. Clark, A history of the Royal College of Physicians of London, 3 vols., Oxford University Press, 1964-72; Sir Zachary Cope, The history of the Royal College of Surgeons of England, London, Anthony Blond, 1959; C. Wall, A history of the Worshipful Society of Apothecaries of London, vol. 1, 1617-1815, London, Oxford University Press, 1963; H. J. Cook, The decline of the old medical regime in Stuart London, Ithaca, Cornell University Press, 1986.

$8 \mathrm{~J}$. Bell and T. Redwood, Historical sketch of the progress of pharmacy in Great Britain, London, The Pharmaceutical Society of Great Britain, 1880, p. 30.
} 


\section{The rise of the English drugs industry}

"write well" by "multiplying their nauseous superfluities". 9 Such devices, underneath the veneer of high ethics, must have been widespread, though we generally know about them only when they became so threatening to the public interest as to require Parliamentary intervention. Thus, in the nineteenth century, physicians who certified the insane were explicitly prohibited from accepting backhanders from privatemadhouse operators, though, as we know from the notorious practices of John Conolly, unscrupulous doctors were still tempted to ride roughshod over the law. ${ }^{10}$

The business of medicine should not be seen, however, simply as a matter of the sale of skills. ${ }^{11}$ For most branches of medicine also dealt more and more in an increasingly significant commodity: drugs. A crescendo of commentators through the seventeenth and eighteenth centuries, many of them practitioners weeping crocodile tears, remarked upon, and, typically, deplored, the vast increase in the consumption of medicaments. Certainly, the supply side of the equation swelled massively between the sixteenth century and the nineteenth. Up to 1600 , the materia medica remained fairly traditional, relying upon simples and the time-honoured herb-based Galenicals. This changed. During the seventeenth century, the importation of drugs from the Orient and the New World soared at least twenty-five fold, and by the Restoration, several hundred kinds of exotic drugs were readily available. ${ }^{12}$ Moreover, many of these newer items-for instance, ipecacuanha and Jesuits' Bark-proved effective and highly popular.

Other developments gave prominence to new drug remedies not available from routine kitchen physic. The Paracelsian and Van Helmontian movements in alchemy and chemistry stimulated the introduction of new mineral, metallic, and chemical medicines, making free use of such laboratory-produced ingredients as aqua fortis, calomel, antimonials, ferrous sulphate, and Glauber's salt. ${ }^{13}$ Iatrochemistry was boosted by the founding of the Society of Chemical Physicians at the time of the Restoration. Significantly, from 1672 onwards, the Society of Apothecaries ran its own dispensary. ${ }^{14}$ Successive versions of the London Pharmacopoeia - there were nine editions from 1621 to 1809 -show an increasing percentage of mineral and chemical cures.

\footnotetext{
9 Ibid.

${ }^{10}$ See A. Scull, 'A Victorian alienist: John Conolly FRCP DCL (1794-1866)', in W. F. Bynum, Roy Porter, and Michael Shepherd (eds.), The anatomy of madness, 2 vols., London, Tavistock, 1985, vol. 1, pp. 103-51.

11 Unfortunately, the history of pharmacy has been little studied. For broad surveys see L. Matthews, History of pharmacy in Britain, Edinburgh and London, E. \& S. Livingstone, 1962; J. Grier, A history of pharmacy, London, The Pharmaceutical Press, 1937; F. N. L. Poynter (ed.), The evolution of pharmacy in Britain, London, Pitman, 1965; J. K. Crellin, 'Pharmaceutical history and its sources in the Wellcome Collections. 1: The growth of professionalism in nineteenth-century British pharmacy', Med. Hist., 1967, 11: 215-27; Bell and Redwood, op. cit., note 8 above. Some of the hidden assumptions in much of this literature are exposed in Holloway, 'The orthodox fringe', op. cit., note 2 above.

12 R. S. Roberts, 'The early history of the import of drugs into Britain', in Poynter (ed.), op. cit., note 11 above, pp. 165-86.

${ }^{13}$ C. Webster, The great instauration. Science, medicine and reform 1626-1660, London, Duckworth, 1975; A. Debus, The English Paracelsians, London, Oldbourne, 1965; O. Hannaway, The chemists and the word, Baltimore, Johns Hopkins University Press, 1975; M. B. Hall, 'Apothecaries and chemists in the seventeenth century', Pharm. J., 28 Oct. 1967, pp. 433-6.

${ }^{14}$ See Cook, op. cit., note 7 above, ch. 4; Bell and Redwood, op. cit., note 8 above, p. 13. The idea of a chemical laboratory was first mooted in 1641 by Edward Cooke, Master of the Society.
} 


\section{Roy Porter and Dorothy Porter}

This increased supply was clearly matched by growing demand. Sick people, all agreed, were no longer satisfied with the ancient regimens recommended back in the good old days of learned physic; they now insisted upon lavish and up-to-date drug therapies. $^{15}$ Physicians blamed the change on unscrupulous apothecaries, who exploited patients' susceptibilities, and on know-all patients' inveterate itch to dose themselves. ${ }^{16}$ Eighteenth-century moralists argued that the corruptions of civilization produced the nervous disorder they called the "English malady", which itself bred hypochondria and led to heavy drug-dependence. ${ }^{17}$

Whatever the causes, the reshaping of medical practice from the late seventeenth century further encouraged liberality in the use of medicines. Dispensaries for the poor, set up first at the end of the seventeenth century by the College of Physicians, and then in the late eighteenth century by lay-financed charities, clearly identified treatment with drugs. ${ }^{18}$ The vast expansion of "irregular" medicine in the eighteenth century depended almost wholly upon the nation-wide advertising, distribution, and sale of patent and proprietary nostrums in unparalleled quantities (nearly two million doses of Dr James' Powders were sold within a twenty-year period). ${ }^{19}$

Possibly most important of all, from 1704 apothecaries enjoyed the legal right to give medical advice (or in effect, to practise physic), so long as they charged only for their medicines. Doubtless, it was also psychologically easier to get patients to pay for boluses or electuaries, more tangible than words. For both reasons, apothecaries' treatment became synonymous in the eyes of their detractors with over-dosing and over-charging. In the late seventeenth century, when Sir George Wheler fell sick and was treated by Sir George Ent, his apothecary's bill came to no less than $£ 28 .{ }^{20}$ Indeed, the Rose Case of 1703-4, which secured the apothecaries' right to prescribe, sprang from the indignation of a butcher, John Seale, when presented by his apothecary, William Rose, with a bill for his year's medicines totalling $£ 50 .^{21}$

Recent research has demonstrated how handsomely apothecaries benefited from a medicine boom they had helped to start. Apothecaries' spokesmen, from the time of their struggles with the College of Physicians around 1700, right through to the

\footnotetext{
${ }^{15}$ Roy Porter, 'The patient in the eighteenth century', in A. Wear (ed.), The history of medicine in society, Cambridge University Press, (forthcoming).

${ }^{16}$ For a classic exposition see B. Mandeville, $A$ treatise of the hypochondriack and hysterick diseases, London, J. Tonson, 1730.

${ }^{17}$ C. A. Moore, 'The English malady', in Backgrounds of English literature, 1700-1760, Minneapolis, University of Minnesota Press, 1953; Roy Porter, 'The rage of party: A Glorious Revolution in English psychiatry?', Med. Hist., 1983, 29: 35-50.

${ }^{18}$ See Cook, op. cit., note 7 above, ch. 6; Bell and Redwood, op. cit., note 8 above, p. 15; Irvine Loudon, 'The origins and growth of the dispensary movement in England', Bull. Hist. Med., 1981, 55: 322-42; L. G. Matthews, 'The Aldersgate Dispensary and the Aldersgate Medical School', Pharm. Historian, 1983, 13: 7-8. Hal Cook has obligingly emphasized to us that many of the developments which we here discuss in respect of the end of the seventeenth century and beginning of the eighteenth had a longer history; we are entirely in agreement with this view.

${ }^{19}$ See W. F. Bynum and Roy Porter (eds.), Medical fringe and medical orthodoxy, 1750-1850, London, Croom Helm, 1986; Roy Porter, 'Before the fringe: quack medicine in Georgian England', History Today, October 1986, pp. 16-22; and idem, Health for sale: quack medicine in England, Manchester University Press, 1989.

${ }^{20}$ See C. J. S. Thompson, The mystery and art of the apothecary, London, John Lane, 1929, p. 199. See also the discussion in Bell and Redwood, op. cit., note 8 above, pp. $18 \mathrm{ff}$.

${ }^{21}$ Holmes, op. cit., note 4 above, p. 186. The College of Physicians actually brought the case.
} 


\section{The rise of the English drugs industry}

attempts of emergent general practitioners to secure legal recognition in the first half of the nineteenth century, liked to paint a David and Goliath picture of apothecaries, the poor, downtrodden, oppressed branch of medicine, standing as the solitary selfless guardians of the public interest against the selfish, monopolistic big guns of the Colleges. ${ }^{22}$ Historians have been known to take this propaganda at face value. ${ }^{23}$

But recent research, above all by Loudon and Burnby, has amply demonstrated that from the mid-seventeenth century onwards a substantial proportion of apothecariescum-general practitioners were themselves basking in new prosperity and upward mobility, confirming the accuracy of Robert Campbell's statement, in his English tradesman (1747), that the apothecary's was a "very profitable trade .... His profits are unconceivable", or the thrust of a hostile pamphlet of 1748 in which "the Apothecaries' monstrous profits are exposed". ${ }^{24}$ All the signs are that emergent general practitioners - for example, the Pulsford family of Wells in Somerset-made the most of the eighteenth-century consumer boom to increase their incomes (or to grow fat upon the public, as their enemies put it). ${ }^{25}$ William Broderip, the Bristol apothecary, had an annual income around the end of the eighteenth century of as much as $£ 6,000$, kept a carriage and coachman, and enjoyed both a town and a country residence. He was exceptional but not unique. ${ }^{26} \mathrm{Up}$ and down the country, wealthy apothecaries were buying property, building houses, making good matches, and holding public office. Some enjoyed the mayoralty: Thomas Macro was five times mayor of Bury St Edmunds. A few apothecaries, such as James St Amand and George Bruere, even rose to become MPs. ${ }^{27}$

The Golden Age of the apothecary-cum-general practitioner saw him leaping over the counter, stepping into the physician's shoes, and becoming a prescriber in his own right, at the same time retaining the apothecary's traditional prerogative of dispensing. This new role, however, also carried its cost. Increasingly out visiting on his rounds, the new-style apothecary necessarily neglected his shop. Perhaps he also came to despise the counter and mere trade. Putting on airs and graces, he upped his charges. At this point, historians tell us, the old David had, in effect, turned into a Goliath who, in turn, met a new David. ${ }^{28}$ For the apothecary's monopoly as dispenser of drugs was challenged"usurped" was the word they used-from the last decades of the eighteenth century onwards by the sudden expansion of the numbers of shopkeeping chemists and druggists filling the vacuum. Having laid nothing out on medical training, and having no costly and time-consuming rounds to make, the druggist could profitably undercut the apothecary-cum-general practitioner when it came to selling drugs. ${ }^{29}$

\footnotetext{
${ }^{22}$ See the discussion in Holloway, 'The orthodox fringe', op. cit., note 2 above.

${ }^{23}$ E.g., F. F. Cartwright, $A$ social history of medicine, London, Longman, 1977, pp. 52-3.

24 See Bell and Redwood, op. cit., note 8 above, p. 27; Thompson, op. cit., note 20 above, pp. 194ff.; on this subject, Burnby, op. cit., note 4 above, is a fundamental work of research and reinterpretation.

${ }^{25}$ Loudon, op. cit., note 4 above.

${ }^{26}$ See idem, 'The Vile Race of Quacks with which this Country is Infested', in Bynum and Porter (eds.), op. cit., note 19 above, pp. 106-28; on Broderip, p. 107.

${ }^{27}$ On this Holmes, op. cit., note 4 above, pp. $229 \mathrm{ff}$. is valuable.

${ }^{28}$ See Loudon, op. cit., note 26 above.

29 Bell and Redwood, op. cit., note 8 above, p. 34; J. M. Good, The history of medicine, so far as it relates to the profession of the apothecary, London, Dilly, 1796, p. 148, for "encroachment". Good urged (p. 227) "the entire restoration ... of retail pharmacy to the apothecary" as "just".
} 


\section{Roy Porter and Dorothy Porter}

Apothecaries represented their new rivals as ignorant interlopers, a public health hazard: for unlike apothecaries, druggists had no prescribed regular training. The apothecaries lobbied Parliament to outlaw dispensing by druggists (it was rightfully the apothecaries' prerogative), and even more urgently, to prevent unqualified druggists from prescribing. In this, as the Apothecaries' Act (1815) shows, they were unsuccessful.

In most historical accounts, chemists and druggists become visible only when country doctors, especially once organized into the General Pharmaceutical Association of Great Britain, founded in 1794, began attacking them. The historian's assumption that the apothecaries' accusations were largely justified possibly reveals an unconscious desire to cast the emergent GP in a heroic light, and a residual snobbishness about retail trade. As a result, the early history of pharmacy has been neglected, and this neglect must be harmful.

For one thing, it has surely led, as we hope to show below, to a misleading account of the nature and chronology of the drugs trade. For another, it means that our picture of the organization and interdependence-the whole economy-of medical practice has become puzzling or distorted. If, for example, as current research seems to be demonstrating, the habit of self-physick was notably more common from the late seventeenth century, it is vital to know the channels through which sick people obtained their medicines. ${ }^{30}$ Moreover, how did physicians and apothecaries themselves obtain their drugs? How many-in 1700,1750 , or 1800 -were still drying their own herbs or distilling their own essential oils? Or were the great majority increasingly buying practically all their materia medica ready-made from wholesalers and middlemen? If that was happening, druggists must thereby assume a crucialthough until now all too shadowy-role as the manufacturers and distributors of the very sinews of medicine. They become integral to that surge of large-scale manufacturing and marketing which we call the Industrial Revolution; they become the authentic progenitors of the pharmaceutical industry.

Of course, these dimensions of the economic history of medicine may well remain hardly visible if we go on equating druggists with ignorant shopkeepers, and assuming that the retail druggist only "first appeared in the 1780s". As a recent account has phrased it, "it does seem certain that the dispensing druggist appeared and multiplied in the last two decades of the eighteenth century":

Previously druggists were nearly always wholesalers, supplying the apothecaries. When the change occurred, however, the druggist started to supply the public with medicine sold over the counter at a much lower price than that charged by medical practitioners. $^{31}$

Of course, there is an element of truth in this view. The trade directories indicate the swiftly increasing presence of chemists and druggists in the late eighteenth century.

\footnotetext{
${ }^{30}$ See the remarks in S. W. F. Holloway, 'The orthodox fringe', op. cit., note 19 above, pp. 129-57, especially pp. 154-5.

${ }^{31}$ See Loudon, op. cit., note 26 above, pp. 108, 109; idem, Medical care and the general practitioner 1750-1850, Oxford, Clarendon Press, 1986, pp. 133ff. Valuable suggestions are offered in J. G. L. Burnby, 'Some Flinders family history: connection with pharmacy', Aust. J. Pharm., 1987, 68: 61-6.
} 
They suggest that many towns-Sheffield is a good example-boasted just a single druggist around 1770 , perhaps six by 1800 , and a dozen or two by the $1820 \mathrm{~s}^{32}$

Yet if our primary interest is not in title and status, nor in inter-professional rivalry between proto-general practitioners and druggists, but rather in the material economics of the medical business, it is important not to be misled by formal terminology. It is not obvious, for example, that this apparent surge in the number of pharmacy shops was real. More were listed, but this may not truly indicate a correspondingly sharp increase in premises serving as pharmacies. For one thing, it says nothing of the earlier sale of drugs by grocers and general shopkeepers. For another, it may indicate that established chemists' shops, formerly run by qualified apothecaries, were increasingly being transferred to tradesmen calling themselves "druggists". Thus one can trace the continuous existence of a pharmacy business in Derby from the mid-seventeenth century. ${ }^{33} \mathrm{Up}$ to 1764 , the premises were run by a succession of apothecaries; from then on, the owner was styled "druggist"; by the early nineteenth century he called himself a "dispensing chemist". There is abundant evidence from the provinces of a sophisticated, shop-based trade in medicines from the seventeenth century, initially chiefly in the hands of apothecaries, but increasingly being taken over, commonly well before 1780 , by mere druggists. John Beatson, for example, was operating as a druggist in Rotherham in 1751, and Wyley in Coventry just a few years later. Similarly, in Chester, a pharmacy had existed since the Restoration. It was traditionally manned by apothecaries-John Goulbourne, John Sudlow, Francis Touchet, and others-from 1722 it was occupied by Peter Ellames, who styled himself "apothecary and druggist", and his sons, in turn, simply called themselves "druggists", apparently preferring retail trade to medical care. We have no reason to suppose that these latter men were any less skilled in the drug business than their predecessors. ${ }^{34}$

The London evidence, as might be expected, reveals an impressively early and powerful presence of shopkeeping druggists operating independently of any medical care. The business of manufacturing chemicals for medicinal and other uses had been strong since the Restoration at least, and in the metropolis, people calling themselves "druggists" rather the "apothecaries" were commanding large slices of the wholesale and retail trade long before the 1780 s. Indeed, as early as the 1740 s, a spokesman for the Apothecaries Company was bitterly complaining that there were already over a hundred chemists and druggists in town, of whom only twenty were "regular". 35 The first figure may not have been an exaggeration. For while the population of druggists in

\footnotetext{
32 See the information in Loudon, op. cit., note 26 above, especially pp. $111 \mathrm{ff}$. There is useful corroboration in G. Fletcher and J. I. Harris, 'Pharmacy in Bath during the Regency period', Pharm. Historian, 1970, 5: 2-4; W. J. Robinson, 'Physick in Bolton in 1779', ibid., 1981, 11: 6-7; W. L. B. Coleman, The chemists and pharmacists of Norwich and district from c. 1800 to 1975, Norwich, The Author, 1977; J. Austen, Historical notes on old Sheffield druggists, Sheffield, Northend, 1961. For some comments on the use of trade directories, see J. G. L. Burnby, ‘Apprenticeship records', Trans. Br. Soc. Hist. Pharm., 1977, 1: 145-94.

${ }^{33}$ For similar information, see idem, 'Some Derbyshire apothecaries', Pharm. Historian, 1970, 5: 5-8.

34 For the crucial importance of the shop see J. K. Crellin, 'Pharmacies as general stores in the 19th century', Pharm. Historian, April, 1979, 9: [unpaginated]; Laurence Dopson, 'The state of London chemists' shops in the 18th and early 19th centuries', Chemist Drugg., Annual Special Issue, 25 June 1955, pp. 718-21; L. G. Matthews, 'The spicers and apothecaries of Norwich', Pharm. J., 1967, $198:$ 5-9.

${ }^{35}$ See Bell and Redwood, op. cit., note 8 above, pp. 33, 34.
} 
Georgian London has never been properly measured, a list casually compiled fifty years ago totals 92 chemist's firms and 52 chemist and druggist businesses in operation at some time during the century, and by no means predominantly near the end. ${ }^{36}$

Not untypical of these was the establishment of John Toovey, druggist and chemist at the Black Lion in the Strand, whose mid-eighteenth century advertisements stated that he made up "all Sorts of Chemical and Galenical Medicines, ... the very best French and English Hungary Waters, Lavender and Mineral Waters, Daffy's and Stoughton's Elixir, etc. Wholesale and Retail ... . Physicians Prescriptions made .... Chests of Medicines for Gentlemen and Exportation." ${ }^{37}$ In London as in the provinces, shops founded by apothecaries tended to be taken over during the course of the century by proprietors simply styling themselves "druggists and chemists", which must sometimes have signalled the fact that they had not undergone a medical apprenticeship. ${ }^{38}$ Thus the Plough Court pharmacy was run from 1715 by Silvanus Bevan, who styled himself "apothecary", but from 1765, it came under the management of Timothy Bevan, who called his premises "Druggists and Chemists". ${ }^{39}$ Indeed, chemists and druggists clearly played a major role in the enterprise of medicine from the latter half of the seventeenth century. The attempt of the apothecaries from the 1790s, particularly through the General Pharmaceutical Association of Great Britain, founded in 1794, to persuade Parliament to ban unqualified dispensing by druggists is often taken as marking the late and sudden rise of such chemists. Against this, however, it must be remembered that the apothecaries had already waged-and lost-an almost identical campaign against the druggists as early as the $1740 \mathrm{~s}^{40}$

Many of the early druggists had businesses big by any standards. In 1710, Anthony Kingsley, a wholesale druggist in Newgate Street, London, went into partnership with his apprentice Edward Pincke and Anselm Beaumont. Between them, they put up capital totalling no less than $£ 8,000 .{ }^{41}$ Numerous other family firms or partnerships in pharmaceutical manufacture prospered right through the eighteenth century. Among them were the Bevans' pharmacy at Plough Court, which eventually became Allen and Hanbury's; Richard Battley's at St Paul's Churchyard, ultimately taken over by Thomas Keating of flea-powder fame; Thomas Fynmore's pharmacy in Aldersgate Street; Samuel Towers's premises in Oxford Road, and Thomas Bratton's in Castle Street. All these businesses had continuous histories stretching forward into the twentieth century. ${ }^{42}$

\footnotetext{
${ }^{36}$ [Anon.] 'Eighteenth-century London chemists', Chemist Drugg., 1937, 127: 178-9; [anon.], 'Retail pharmacy over one hundred years', Pharm. J., 1941, 141: 130-63.

37 Burnby, op. cit., note 4 above, p. 53.

38 Ibid., p. 60.

${ }^{39}$ E. C. Cripps, Plough Court. The story of a notable pharmacy, London, Allen and Hanbury, 1927; D. Chapman-Huston and E. C. Cripps, Through a city archway: the story of Allen and Hanbury, 1715-1954, London, Murray, 1954.

${ }^{40}$ Loudon, op. cit., note 26 above, esp. pp. $118 \mathrm{ff}$; Holloway, op. cit., note 30 above, pp. 130ff.; Bell and Redwood, op. cit., note 8 above, pp. 36ff.; Wall, op. cit., note 7 above, p. 148.

41 Matthews, op. cit., note 11 above, p. 215.

42 Matthews, op. cit., note 11 above, pp. 224ff.; [anon.], 'Pharmaceutical houses of London', Chemist Drugg., 1953, 575-8. See also J. G. L. Burnby, 'The Towers and the Huskissons', Pharm. J., 21 June 1980, pp. 716-18.
} 


\section{The rise of the English drugs industry}

Some grew to an impressive size. William Jones's firm provides a good instance. ${ }^{43}$ Jones first practised as a druggist in Little Russell Street, in 1757 moving, rather appropriately, to premises in Great Russell Street as his operation expanded. He secured the plum contract for supplying antimony and cream of tartar to Dr Robert James, patentee of Dr James' Fever Powders (his order book for 1772 notes "the usual 500lb of antimony" for James). Jones personally undertook twice-yearly rides around the country angling for orders, and exploited the business potential of the newly-founded county hospitals by securing contracts to supply the infirmaries at Chester, Hereford, Salisbury, and Stafford. Over a period of many years he sold drugs valued at nearly $£ 200$ per annum to the Westminster Hospital. Jones traded wholesale to apothecaries and surgeons all over the Midlands and the West Country, and also developed a giant export trade, particularly with the West Indies, Canada, Gibraltar, and the East India Company, as.well as with France. So successful was he, that he turned part-time banker, bill-broker, and money-lender-he loaned money to John Hunter-, handled India Bonds for his customers, and dealt in lottery tickets and fire insurance. Yet he did not neglect his shop and retail business: his accounts show him selling ten-penny quantities of senna, laudanum, and sassafras to individual customers. When John Hunter urged Edward Jenner to set up "Jenner's Tartar Emetic" as a nostrum, he thought Jones would market it best.

A similar story could be told for the pharmacy which Silvanus Bevan took over from Salem Osgood at Plough Court in 1715. ${ }^{44}$ The business was passed down to his brother Timothy in 1765, then to his sons, Timothy II and Silvanus II, and subsequently on to Joseph Gurney Bevan, who ran it until 1794, when it was acquired, briefly, by Samuel Mildred. Mildred in turn went into partnership with William Allen, who finally took on Luke Howard as his partner. The business was clearly stable and prosperous.

Through the century, the bulk of the Plough Court trade lay in drug manufacture and distribution, though a retail department was retained, and Silvanus Bevan practised physick from the shop. The business, in Quaker hands, had a reputation for high standards of purity and fair dealing: the drugs, it was explained, were genuine rather than cheap. Unfortunately - and this is true of much written on early pharmaceutical concerns - the day-to-day business history of the pharmacy from the Bevans to Allen and Howard is little known. Two full-length books have been written about Plough Court and its proprietors, but these volumes, echoing all the traditional snobberies, dwell upon the high-mindedness of the Bevans, of Allen and Howard: their practical philanthropy, their part in crusading against the slave trade, their contributions to the sciences of chemistry, mineralogy, meteorology, and geology. But they say almost nothing about the networks of buying and selling pharmaceuticals, the economy connecting wholesale chemical suppliers and the doctors and medical institutions which purchased their wares, or indeed about the capital, investment, and profit involved. ${ }^{45}$

\footnotetext{
${ }^{43}$ Extremely valuable for the following details is G. M. Watson, 'Some eighteenth-century trading accounts', in Poynter, op. cit., note 11 above, pp. 45-78. See also Burnby, op. cit., note 4 above, p. 51.

${ }^{44}$ See Cripps, op. cit., note 39 above; Chapman-Huston and Cripps, op. cit., note 39 above.

${ }^{45}$ See Cripps, op. cit., note 39 above; Chapman-Huston and Cripps, op. cit., note 39 above. The latter book has some discussion of exports, (pp. 38ff.). These works at least have the merit of demonstrating that mere druggists were not "marginal men". For important confirmation of this point, see P. Weindling, 'Geological controversy and its historiography: the prehistory of the Geological Society of London', in
} 
Though the drugs trade became the linchpin-even the epitome-of the practice of medicine, we have no structured analysis of it, nor any clear idea of its financial dimensions.

In the rest of this paper, we aim to make a preliminary contribution to this basic research task by discussing the business records of one of the largest-though almost wholly neglected-eighteenth-century pharmaceutical manufacturers, Thomas Corbyn, the bulk of which have recently been acquired by, and are available at, the Wellcome Institute for the History of Medicine. ${ }^{46}$

A Quaker, born in Worcestershire in 1711, Thomas Corbyn was apprenticed in 1728 to Joseph Clutton, a London apothecary, also from Worcestershire ${ }^{47}$ Clutton had real medical interests, though it is not known to what extent it was medicine or the pharmacy trade which earned him his living. On Clutton's death in 1743, Thomas Corbyn got his freedom from the Society of Apothecaries, and jointly ran the business with Clutton's widow, a development which suggests that its pharmaceutical side was already well established. Indeed, shortly before Clutton's death, and presumably anticipating it, Corbyn began to send out batches of letters over his own name to correspondents, chiefly abroad, offering to supply them with compound medicines, etc. ${ }^{48}$

In 1747, Corbyn entered into a partnership with Clutton's son, Morris, himself freed from the Apothecaries Company in that year. Each put up nearly $£ 2,000$ in capital. ${ }^{49}$ Morris Clutton died, however, just seven years later, and Corbyn, having successfully raised thousands of pounds in capital to buy out Clutton's heirs, took over the business single-handed. ${ }^{50}$ This arrangement did not prove permanent, and Corbyn traded with a succession of partners for the last thirty years of his life. In 1762 , for instance, he entered into an agreement with John Brown and Nicholas Marshall. Marshall evidently proved to be somewhat dubious in his business affairs, and for some time after his death in 1776 much of Corbyn's correspondence was preoccupied with sorting out the mess he left behind. By 1781, Thomas Corbyn's partners were his son John, John Brown, John Beaumont, and George Stacey; in 1787, Brown was replaced by Josiah Messer; in 1795, Beaumont dropped out; and so forth. By the later part of the nineteenth century, the enterprise was known as "Corbyn and Stacey". 51

L. J. Jordanova and R. Porter (eds.), Images of the earth, Chalfont St Giles, British Society for the History of Science, 1979, pp. 215-47.

${ }^{46}$ Cited henceforth as "Wellcome Corbyn Papers". The contents are described in a typescript finding list, 'Corbyn and Co, Chemists and Druggists, London'. They form Western MSS 5435-5460. It should be emphasized here that this present article is intended to offer no more than a general outline of Corbyn's activities, based upon preliminary work on these papers and others (e.g. sales catalogues) available at the Library of Pharmaceutical Society of Great Britain. It is hoped to publish further work in the near future, examining particular aspects of Corbyn's business in greater depth, on the basis of more systematic study of these manuscripts.

${ }^{47}$ For an extremely valuable introduction to Corbyn, see T. D. Whittet and J. G. L. Burnby, 'The firm of Corbyn and Stacey', Pharm. J., 1982, 228: 42-8; and the discussion in Burnby, op. cit., note 4 above, pp. 49-51.

48 Ibid., pp. 49-50.

49 Wellcome Corbyn Papers, 5437.

${ }^{50}$ Reconstructed from Wellcome Corbyn Papers, co-partnership agreements, 5438, 5439.

${ }^{51}$ See deeds and contracts in Wellcome Corbyn Papers, 5438, 5439, 5453-6, 5459. 
What was the nature of the business? Joseph Clutton seems to have combined operating as a chymist with a certain interest in medicine itself. Amongst other things, he published $A$ short and certain method of curing continuous fevers. ${ }^{52}$ There is no sign, however, that either Thomas Corbyn or Morris Clutton, though freemen of the Apothecaries Company, spent any time caring for the sick. In legal documents, Corbyn was habitually referred to as a "chymist" or "druggist", rather than "apothecary", (though he occasionally styled himself a "wholesale apothecary"). To one correspondent he wrote, "the drug trade is my proper business", noting quite candidly that "it will pay better than any other merchandize". ${ }^{53}$

Corbyn's business lay in the manufacture and sale of drugs, both wholesale and retail, though the former comprised the heart of the enterprise. Catalogues, stock-lists, warehouse records, and elaborate recipe books reveal that Corbyn's made and vended simple drugs like senna, rhubarb, clove oil, arrow root, and bark; compound medicines and galenicals, such as theriac, tartar emetic, Balsamic Tincture, Hungary Water, Citron Water, and hundreds more; and manufactured, or sold, nostrums like Bateman's Pectoral Drops, Daffy's Elixir, and such toiletries as dentrifice. ${ }^{54}$ Joseph Clutton had marketed his own nostrum, "Clutton's Febrifuge", but Corbyn - who had a reputation as a stern, no-nonsense Quaker-never attached his own name to proprietary medicines, and nostrum-mongering amounted to only a sliver of the business. Indeed, what is impressive is the dedicated care Corbyn's put into the manufacture of high-quality drugs, made to the College Pharmacopoeia standards.

The Company possessed massive recipe books, listing the ingredients and proportions for several hundred different preparations, together with lengthy and precise instructions for pounding, blending, distillation, and so forth. Many of the recipes have notes appended in later hands, which record experiments for improving manufacturing techniques, occasional failures, recommendations for alternative methods, tips for removing impurities or eradicating unpleasant coloration, and so forth. ${ }^{55}$ Most recipes contain itemized costing details, and recommended wholesale prices for the finished product. Thus, for instance, Edinburgh Theriac could be made up by two different processes, one costing $30 s$. per pound, the other $23 s .{ }^{56}$ Corbyn's letters to his customers reveal that he relied on consistent quality, not cheapness or innovation. In 1750 he wrote to John and Esther White in America, ${ }^{57}$

The simple drugs are ye best of their kind, and ye compositions not only true, but curiously prepared, and charg'd reasonable according to ye present market prices. . . Perhaps some will say ye compositions are too dear, thou must insist on their

${ }^{52}$ See Whittet and Burnby, op. cit., note 47 above; Wellcome Corbyn Papers, 5436, item 11.

53 Wellcome Corbyn Papers, 5442, Foreign Letter Book, p.98, letter to Samuel Bowne, 7 June 1748.

54 Wellcome Corbyn Papers, 5451, Preparationes chymicae et galenicae, a large folio printed broadside (1747); for Corbyn's inventory, see 5452. See also Roy Porter and Dorothy Porter, In sickness and in health: the British experience 1650-1850, London, Fourth Estate, 1988; and Dorothy Porter and Roy Porter, Patient's progress, Cambridge, Polity, 1989.

55 Wellcome Corbyn Papers, 5450 (1); 5450 (2) is more-or-less a copy. They run to over 200 pages, and are alphabetically arranged. The annotations date from 1748 to 1841 .

${ }^{56}$ Wellcome Corbyn Papers, 5450 (1).

57 Wellcome Corbyn Papers, 5442, Foreign Letter Book, p.76, 7 March 1747. 


\section{Roy Porter and Dorothy Porter}

goodness. I know there are a great many very bad and adulterated medicines sent to America, which are sold cheap but have much larger proffitt than those who are conscientious in preparing them true according to ye London dispensatory.

This approach evidently paid off well, for Corbyn's business grew rapidly but lastingly. In 1750 he could write to Cadwallader Evans, "we confine ourselves pretty much to the Drug Trade, being considerably increas'd". 58

Corbyn traded from premises at $\mathbf{3 0 0}$ Holborn (later, further premises were taken at Poultry in the City). He had a separate laboratory, and a vast warehouse in Cold Bath Fields. His warehouse stock book or inventory, dated December 1761, runs to 2,500 different items of materia medica, which were stored in extraordinarily large quantities-he held 276 pounds of senna and 806 of magnesia alba for example. ${ }^{59}$ Corbyn also made up his drugs in impressively large batches: the recipes not infrequently require ingredients by the hundred-weight. Thus, that for bark extract begins with instructions to digest 150 pounds of bark with 90 gallons of spirit; similarly, the recipe books envisage making up tartar emetic to 365 pounds. Corbyn's records show that compound medicines were manufactured in batches whose cost price often ran to $£ 50$ or more, and whose wholesale value to Corbyn may have been twice that amount. ${ }^{60}$

Surviving wage books likewise confirm the scale of the concern. The evidence here is fragmentary, but it appears that the firm had in the region of ten employees at any one time in the $1760 \mathrm{~s}$, some of whom were presumably apprentices, and others journeymen. ${ }^{61}$ The pricings in the recipe books often include a substantial sum under "labour", ten shillings for instance. Drug manufacture was undoubtedly labourintensive, involving as it did a long series of stages from bidding at auctions held at Garraway's Coffee House and elsewhere for sacks of raw supplies straight off the East India vessels, through to the final dispatch of orders in neatly-labelled glass bottles, sent across the world, properly packed, insured, and addressed. One set of instructions for preparing ambergris for sale notes that 73 pounds were purchased from John Wheeler; it was refined in " 40 operations", requiring 20 bushels of coal and one man's time for seven weeks (the cost of the labour came to $£ 3.6 s .8 d$.). ${ }^{62}$

Other scraps of evidence suggest that Corbyn's was a very busy enterprise. A surviving page of a day book, listing a day's business and takings - interestingly it is for Christmas Day 1761, or "25.12." as Corbyn, staunch Quaker, insisted on calling it-seems to indicate that about 120 separate items were made up that day, comprising about a dozen orders. ${ }^{63}$

The real proof of the scale and success of the enterprise is contained in some fragmentary accounts for the partnership, and by extensive, though often tantalizing,

\footnotetext{
${ }^{58}$ Ibid., p.132, 18 April 1750.

59 Wellcome Corbyn Papers, $5452(1-4)$, Inventory, 1761. The inventory is in four folio volumes, totalling 59 pages. It gives the precise physical location of each item within the warehouse.

60 Wellcome Corbyn Papers, 5450 (1), recipe book.

61 Wellcome Corbyn Papers, 5445.

62 Wellcome Corbyn Papers, 5450 (1). In general, we have only the scantiest information about Corbyn's suppliers of raw materials. His letters to American correspondents give little indication of purchasing from them.

${ }^{63}$ Wellcome Corbyn Papers, 5439 (18, 21).
} 
legal bonds, records of loans, borrowings, and partnership agreements. These indicate the magnitude of capital involved. In the 1750s, Thomas Corbyn borrowed upwards of $£ 7,460$ from private individuals, mainly Quakers. Joseph Scott alone loaned him $£ 2,400$ and he obtained $£ 600$ from his fellow chemist, Timothy Bevan. ${ }^{64}$ There is not the slightest indication that the firm suffered any financial crisis; rather, it seems that Corbyn borrowed so heavily in order to underwrite and expand his export trade. The fact that cautious Quakers were willing to vest their money in him indicates their confidence in the enterprise. Indeed, none of the firm's records, through well into the nineteenth century, gives the slightest hint of any real financial upsets consequent upon over-expansion, bad management, or even external events.

When Morris Clutton and Thomas Corbyn went into partnership in 1747, the business seems to have been worth about $£ 4,000 .{ }^{65}$ Subsequent documents suggest that by the 1780 s it was worth around $£ 20,000$. For one year only, 1770, do we have a clear profit-and-loss account. This shows that the total stock at the beginning of the year amounted to $£ 5,545$. Each month, fresh stock to the value of between $£ 700$ and $£ 1,400$ was purchased. Overall, the firm laid out $£ 9,452$ on raw materials in that year (unfortunately, we have hardly any information as to how Corbyn obtained his basic supplies). The firm incurred something like $£ 2,000$ of further expenses (presumably wages, leases, rates, taxes, and the like). Sales fluctuated from month to month, from a low of $£ 493$ in December to a peak of $£ 2,150$ in February; total sales amounted to $£ 13,966$. As a result, Corbyn's operated with a balance of just over $£ 2,114$ clear profit on the year, a tidy sum for frugal Quakers, even when split between four partners. ${ }^{66}$

Moreover, like all businessmen then, Corbyn spread his irons among several fires. He often shipped consignments of other merchandise alongside his medicaments to his overseas agents and customers-gloves, shoes, or haberdashery. ${ }^{67}$ And above all, he inevitably acted as a bill-broker, discounter, and de facto banker, especially to his overseas clients. In fact, a high proportion of the surviving business records comprise legal or quasi-legal records of financial transactions. It is hard to say whether Corbyn and his partners voluntarily undertook these dealings: some must have unavoidably arisen out of the necessity of collecting debts from deceased clients' estates, or from clients who defaulted or could pay only through the most Byzantine financial manipulations. Certainly, bad debts were a constant nightmare. All the same, Corbyn was never less than strict in his financial dealings-the business letters show him to have been a veritable money-making machine-and it is most unlikely that he undertook these general financial services without advantage to himself. ${ }^{68}$

How much, then, was the business actually worth? We lack the continued runs of figures with which we could answer this question. But a balance sheet of the partnership between Corbyn and Morris Clutton between 1746 and 1754, the year

\footnotetext{
${ }^{64}$ Wellcome Corbyn Papers, 5439, 5440 passim. Many deeds and bonds are to be found here.

65 Wellcome Corbyn Papers, 5439.

${ }^{66}$ Wellcome Corbyn Papers, 5439 (especially item 18), 5437 (1).

${ }^{67}$ Wellcome Corbyn Papers, 5442, Foreign Letter Book. The early letters in particular are full of requests for such items. Presumably Corbyn was able to drop these peripheral trades as his business grew more prosperous.

${ }^{68}$ Wellcome Corbyn Papers, 5436, 5439, 5460.
} 
Clutton died, gives some indication of its early scale. Between them, they invested nearly $£ 4,000$ in the partnership. By the time Clutton died, the concern seems to have been worth close to $£ 14,000$. In other words the business had expanded by about $350 \%$ within eight years. How did this break down? In 1754, some $£ 3,293$ was tied up in stock. A further $£ 1,520$ was accounted for as "good debts" in what was known as the "Town Apothecaries Ledger", which recorded purchases made by London dispensing apothecaries. Then, $£ 5,318$, which obviously formed the bulk of Corbyn and Clutton's domestic wholesale trade, was listed in the "Country Ledger". A further $£ 105$ was in their "Patients' Ledger", presumably the retail business. And another $£ 1,978$ came from good debts in their "Foreign Ledger". Unfortunately it is not possible to make a breakdown of the changing fortunes of the business from year to year. ${ }^{69}$

But every indication is that it grew steadily. Drafts of letters show that Corbyn's agents overseas routinely owed him sums which ran into several hundreds of pounds, and occasionally into four figures. An inventory of the estate of one of the partners, John Beaumont, taken in 1794, shows he was worth a very respectable $£ 23,000$, though a proportion of this certainly derived from lands he owned. ${ }^{70}$

With whom did Corbyn trade? Mention of a "Patient's Account" proves that he had a retail trade, probably both over the counter and by post. This was marginal to the business's overall profits, although its existence helps underline the fact that it would be anachronistic to posit any rigid division between wholesale and retail druggists for this period. Our records of the remainder of Corbyn's domestic trade are slight. There is no surviving correspondence for this branch of the business, and we must rely upon the scanty evidence of a few sales ledgers. These demonstrate that Corbyn's attracted a certain amount of custom from the most fashionable metropolitan practitioners, including John Ranby, Messenger Monsey, William Bromfield, and John Fothergill. (Fothergill, another Quaker, was also a personal friend). ${ }^{71}$ More lucratively the business also received a number of regular, substantial orders annually. Several of these came from such London Hospitals as St George's, Guy's, and St Thomas's. In 1764, for example, St George's bought $f 127$ of goods from Corbyn's. Accounts running into hundreds of pounds were also formed with London apothecaries, mainly, one presumes, those who did a handsome trade by dispensing for fashionable physicians. Corbyn's also got business from other London manufacturing chemists, including Sylvanus and Timothy Bevan (who seem to have bought goods worth about $£ 30$ a year), and Dalmohoy (who in 1762 spent $£ 30$ with Corbyn). ${ }^{72}$

But most of the orders-we are talking of hundreds - came from provincials, many of whom are identifiable as country surgeons and apothecaries. Typically, a sum of between $£ 5$ and $£ 30$ changed hands annually: Daniel Sutton the inoculator, for

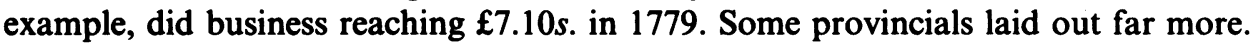

\footnotetext{
69 Wellcome Corbyn Papers, 5451-52.

70 Wellcome Corbyn Papers, 5458.

71 See R. Hingston Fox, Dr John Fothergill and his friends, London, Macmillan, 1919, pp. 264, $282,339$.

72 Wellcome Corbyn Papers, 5437 (1).
} 
Thus John Bogle, the Glasgow surgeon, bought goods worth $£ 217$ in 1764 . Presumably many of these country customers were small-town druggists or owners of general stores. Since some are listed with " \& Co.", it is reasonable to suppose that some were middlemen, shippers, merchants, and smaller wholesalers. ${ }^{73}$ It is not known precisely how Corbyn attracted provincial custom. He certainly travelled on business outside London, however, and he, his partners, or their agents may well have ridden around the country, acting the part of early commercial travellers. The account books list "presents" of drugs: if these were not charitable gifts, they may have been free promotional samples. ${ }^{74}$ What is clear beyond doubt is that no small part of Corbyn's trade was stimulated and sustained by the Quaker grapevine.

Corbyn's domestic trade was substantial, although for want of documentation it remains obscure. Thanks to the survival of letter-books, we know more about his exports, and all the signs are that export came to constitute the key growth sector in his business, and to provide the bulk of the profit. Joseph Clutton may or may not have exported drugs on any scale. Copies of the relevant letters, beginning a brand-new letter-book, reveal beyond doubt, however, that in the months before Clutton's death the young Thomas launched a massive export drive. He made contact with a couple of dozen people abroad, a few in continental countries such as Portugal, but principally in the Americas, ranging from Nova Scotia and New England southwards to Jamaica and Antigua. These were surgeons, physicians, dealers, and general agents. Some were personally known to him; most were not. Almost all were Quakers. ${ }^{75}$

Corbyn's technique was to dispatch, unasked, a chestful of drugs, probably about $£ 50$ worth. He would suggest to the recipients that they do business on a sale-or-return basis, and asked them to distribute the drugs, parcelled up into appropriate quantities, to local medical practitioners and also to planters and other substantial personages (he considerately enclosed a supply of small bottles and vials for the purpose). Corbyn specified a minimum wholesale price, below which he was, as a rule, unwilling to go, as well as an "advanced" price. Sometimes he would also send lists of potential purchasers he wished his agents to contact, occasionally accompanied by a word of diplomatic advice: he recommended that Isaac Greenleaf, for example, make contact with William Goldsborough of Choptank, Maryland, but warned, "act with caution, he's Jno. Hanbury's friend". The overriding aim was to encourage his contacts to extend outlets. As he instructed Greenleaf, in New York, ${ }^{76}$

Endeavour to settle a Correspondence with proper Merchants for disposal of drugs per commission, at the four following places, viz., Williamsburg, Virginia; Anapolis, Maryland; New York, Newport, Rode Island.

\footnotetext{
${ }^{73}$ Wellcome Corbyn Papers, 5439 (12,18). Corbyn lists the names of his purchasers but not their addresses, making the task of tracking them down for the most part extremely difficult. For the supplying of a provincial general shopkeeper, who sold drugs alongside groceries and other merchandise, see T. S. Willan, An eighteenth-century shopkeeper: Abraham Dent of Kirkby Stephen, Manchester University Press, 1970.

74 Wellcome Corbyn Papers, 5439 (5).

75 Wellcome Corbyn Papers, 5442, Foreign Letter Book, provides overwhelming evidence.

${ }^{76}$ Wellcome Corbyn Papers, 5442, Foreign Letter Book, p.36, 15 March 1745. See also C. Spiers, 'The drug supplies of George Washington and other Virginians', Pharm. Historian, 1977, 7, no. 1.
} 


\section{Roy Porter and Dorothy Porter}

To this end, Corbyn enclosed for Greenleaf the draft of a letter he wanted despatched to such people. It began: ${ }^{77}$

I have herewith sent a small chest, a sortment of those articles in most common use, which are choice good of their kind, and to judges will recommend their selves. My design is to supply yee with a proper stock and sortment that thou may serve the doctors and planters, especially those who do not commonly send their orders directly to London.

Corbyn instructed his agents that the articles might be split up into proper saleable quantities, stating that he was including both items of materia medica and also compounds like Stoughton's Elixir, and Bateman's Pectoral Drops.

Agents were obviously free to make what profit they could. They were, however, to send closely-itemized sales details to Corbyn-ever attentive to the minutiae of the trade - and to arrange for bills which could be drawn upon London bankers. They were given twelve months' credit: Corbyn knew that he could not expect payment sooner, but would chivvy if it were delayed much longer. He was constantly seeking enlightenment from his informants about possible new markets. Whence did the locals already get their drugs, from London or elsewhere? How did Corbyn's prices compare? What sort of items were in ready supply, or in demand? Corbyn allowed his agents some discretion, but was not slow to chide them when they ignored his instructions, or indeed seemed likely to become tardy payers. ${ }^{78}$

Corbyn's bold initiative paid excellent dividends. One surviving letter book contains copies of some 550 business letters, mainly from Corbyn himself to his outlets on the other side of the Atlantic in the period from $1742-55 .{ }^{79}$ They chronicle the immense difficulties of dealing over several thousand miles: endless losses, breakages, spoilage, market vagaries, bad debtors, and so on. But they also demonstrate that these were triumphantly overcome by a man of resolution and an iron business temper. Most of Corbyn's outlets clearly had no difficulty in disposing of drug consignments, and they seem to have been happy to deal with him. Letter after letter to such dealers as John Pleasants of Virginia, George Robins of Maryland, Samuel Sansom, Thomas Lightfoot, Israel Pemberton, Esther White, Edward Pennington, and Christopher Marshall (a cousin of John Bartram the naturalist), all of Pennsylvania, Daniel Lathrop of Norwich, Connecticut, John Easton and Jabez Bowen of Newport, Rhode Island, Elijah Collins of Boston, Samuel Bowne, and Peter Renaudot of New York, Robert James of Antigua, Magee of Nova Scotia, Cadwallader Evans of Jamaica, and Dr Joseph Gamble of Bridgetown, Barbados, testify to sound business relations, giving details of further batches being made up, packed in chests or casks, insured, and sent down to Bristol to await ship.

The business went from strength to strength. Some agents traded very heavily. As early as 1762 , John Hunt owed Corbyn $£ 5,640 .{ }^{80}$ A letter-book from the early nineteenth

\footnotetext{
77 Wellcome Corbyn Papers, 5442, Foreign Letter Book, p. 36, 15 March 1745.

${ }^{78}$ For good instances see Wellcome Corbyn Papers, 5442, Foreign Letter Book, correspondence with Christopher Marshall, to be found on pp. 94, 97, 98, 101, 104, 112, 120, 131, 134, 135, 139, $153,171$.

${ }^{79}$ Wellcome Corbyn Papers, 5442, Foreign Letter Book. For an invaluable general introduction to contemporary relations between English and American Quakers, see R. P. Stearns, Science in the British colonies of America, Urbana, University of Illinois Press, 1970.

${ }^{80}$ Wellcome Corbyn Papers, 5438.
} 


\title{
The rise of the English drugs industry
}

century shows a similar trade pattern, but with even larger quantities. One Canadian agent, William Philipps of Halifax, Nova Scotia, was routinely sending orders, of which some were for colonial hospitals, totalling thousands of pounds. Dealings with Australia begin to appear. ${ }^{81}$ And there is evidence of overseas customers contacting the firm on their own initiative. Thus, a letter dated 4 November 1828 , from one Peter Stryker, of Somerville, New Jersey: ${ }^{82}$

\begin{abstract}
Gentlemen,
Having it in contemplation in consequence of the increasing population of our village and its vicinity, to set up an apothecary's shop in the village of Somerville in which I reside-have thought it expedient to embrace the opportunity afforded by my friend A. Stoadart Esq of the City of London and on his recommendation to send you this small medical order, which I hope will be executed on a credit sufficient for me to make a remittance in season to meet your expectations.
\end{abstract}

Stryker went on to ask the prices of various articles, and attached an order running to no fewer than 130 items, beginning with seven pounds of opium and including most of the standard materia medica, as well as bottles, stoppers, and so forth.

Corbyn and Partners were one of the number-probably a few dozen-of large London firms of druggists which emerged during the eighteenth century. In many cases, no records exist. However, sufficient papers survive from Corbyn's, the Plough Court pharmacy, Jones's and a few others, to make serious research on the eighteenth-century origins of the pharmaceutical industry a viable, as well as a fascinating, project. For now, we should like to suggest a few interim conclusions.

First, the Quaker connection was of quite paramount importance to Corbyn's rise to prominence. His correspondence proves that it was the moral and business codes of the Quaker International which made long-distance, indeed trans-Atlantic, trade in drugs a viable enterprise. ${ }^{83}$ The young Corbyn was able, with confidence, to send large and expensive consignments of drugs to people who had never heard of him, and they, in turn, felt able to buy from him with confidence, and all essentially because they had a special relation with those people they habitually addressed as "Loving Friend". They felt trust in their business probity, and anyway knew that in the case of default, the Quaker community would not be slow to put on the screws. Such credit and confidence were absolutely indispensable to the rapid expansion of long-distance trade.

Second, it would be likewise difficult to exaggerate the significance of overseas markets-Corbyn in North America, Jones with the East India Company-for the expansion of the pharmaceutical trade. Alfred Crosby has suggested that eighteenthand nineteenth-century British imperialism could hardly have been so successful without the drugs which rendered unhealthy tropical environments rather less crowded with white man's graves, or indeed black slaves' graves, than they might

81 Wellcome Corbyn Papers, 5443, Foreign Letter Book.

82 Wellcome Corbyn Papers, 5441 (3/9).

${ }^{83}$ A. Raistrick, Quakers in science and industry, Newton Abbot, David and Charles, 1968; M. Stiles, 'The Quakers in pharmacy', in Poynter (ed.), op. cit., note 11 above. 
have been. ${ }^{84}$ Richard Sheridan has recently shown how extensive were the medical arrangements necessary to keep the plantations going. Because the colonies and even the independent United States were slow to develop their own drugs industries, the pickings available for London firms prepared to take risks, time, trouble, and expense, were rich indeed. ${ }^{85}$

Third, business records like Corbyn's indicate that we need to revise our stereotypes of the druggists. Doubtless, some were as the apothecaries represented them: vermin who scuttled in to occupy the shops vacated by the apothecaries themselves; ignorant hucksters out to make a fast buck; threats to health because of their medical ignorance, their passion for committing adulteration. Yet some druggists, at least, and we may never know how many, were not like this at all: they were neither ignorant, nor parasitical, nor dangerous. It was certainly not the case that the druggists' trade attracted only lowly, ill-lettered men who had failed to obtain the training which would have qualified them as apothecaries. A scrupulous man such as Corbyn could easily have chosen to practice medicine as an apothecary. Instead, he preferred to manufacture drugs, because that line of trade interested him more, or, most probably, because he realized that the drugs trade was a far more lucrative business. The Bromfield medical dynasty may give another illuminating instance. The eldest son of the first Thomas Bromfield chose to become a druggist; the Bromfield who became a physician was a third son, by a later marriage. As Burnby has remarked, the snobbery which assumes that it was infra dig. to be a druggist may be ours more than theirs. ${ }^{86}$

Maybe the "adulteration" slur also requires re-examination. Corbyn was a highly skilled manufacturing chemist and a shrewd business man. He knew his trading reputation hinged upon reliable, high quality products. "I could make $100 \%$ profitt by adulteration", he once boasted. ${ }^{87}$ Such a profit-conscious man knew that adulteration would prove to be a mistake in the long run. Purity and consistency meant more to his success than innovation, science, or mere novelty. One might even reverse the arrow of accusation, and hypothesize that the large manufacturing chemists supplied relatively pure drugs; whereas it was the small-town apothecary, faced with treating the sick poor who could not pay their bills, with the necessity of dispensing a bewildering variety of medicines, and with direct requests for cordials and the like, who might well be tempted to adulterate.

Finally, after too much academic neglect and condescension, it is surely time to acknowledge the key importance of the druggists' emergence to the whole organization, structure, and enterprise of medicine. It is surely beyond dispute that, for better or worse, medical practice came to depend ever more heavily upon the trade in medicines, from the rich hypochondriacal patient with his annual apothecaries' bill of several hundred pounds, down to the dispensary itself with its free drugs for the

\footnotetext{
84 A. Crosby, Ecological imperialism: the biological expansion of Europe, 900-1900, Cambridge University Press, 1986.

${ }^{85}$ R. Sheridan, Doctors and slaves: a medical and demographic history of slavery in the British West Indies, 1680-1834, Cambridge University Press, 1985.

86 Burnby, op. cit., note 4 above, p. 50.

87 Wellcome Corbyn Papers, 5442, Foreign Letter Book, p.72, 24 February 1747.
} 
The rise of the English drugs industry

poor. We too rarely remember, however, that none of this could have taken place if all grades of clinical practitioners, hospitals, dispensaries (one might add, ships and armies), and, not least, the self-medicating individuals themselves, had not had ready access to reliable supplies of a gamut of medicaments. The making and marketing of drugs provided the commodity upon which the modern business of medicine was founded. 